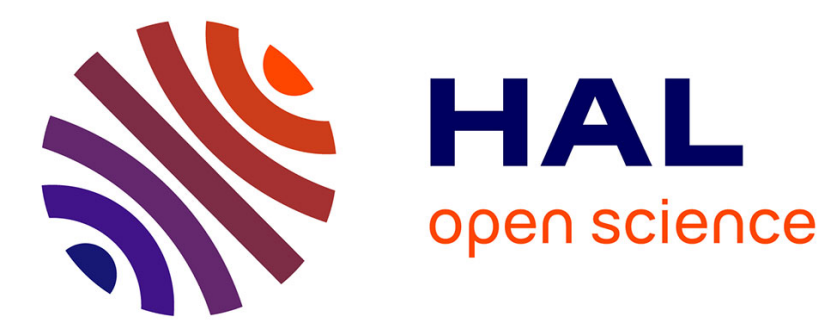

\title{
Orchestrating platform ecosystems : the interplay of innovation and business development subsystems
}

Thierry Isckia, Mark de Reuver, Denis Lescop

\section{To cite this version:}

Thierry Isckia, Mark de Reuver, Denis Lescop. Orchestrating platform ecosystems: the interplay of innovation and business development subsystems. Journal of Innovation Economics \& Management, 2020, Managerial Innovation and Open Innovation Strategies, 32, pp.197-223. 10.3917/jie.032.0197 . hal-02548106

\section{HAL Id: hal-02548106 \\ https://hal.science/hal-02548106}

Submitted on 8 Feb 2021

HAL is a multi-disciplinary open access archive for the deposit and dissemination of scientific research documents, whether they are published or not. The documents may come from teaching and research institutions in France or abroad, or from public or private research centers.
L'archive ouverte pluridisciplinaire HAL, est destinée au dépôt et à la diffusion de documents scientifiques de niveau recherche, publiés ou non, émanant des établissements d'enseignement et de recherche français ou étrangers, des laboratoires publics ou privés. 


\title{
ORCHESTRATING PLATFORM ECOSYSTEMS: THE INTERPLAY OF INNOVATION AND BUSINESS DEVELOPMENT SUBSYSTEMS
}

\author{
Thierry Isckia, Mark De Reuver et Denis Lescop
}

De Boeck Supérieur | «Journal of Innovation Economics \& Management »

2020/0 Prépublication | pages I74 à XXVII

Article disponible en ligne à l'adresse :

https://www.cairn.info/revue-journal-of-innovation-economics-2020-0-page-I74.htm

Distribution électronique Cairn.info pour De Boeck Supérieur.

(C) De Boeck Supérieur. Tous droits réservés pour tous pays.

La reproduction ou représentation de cet article, notamment par photocopie, n'est autorisée que dans les limites des conditions générales d'utilisation du site ou, le cas échéant, des conditions générales de la licence souscrite par votre établissement. Toute autre reproduction ou représentation, en tout ou partie, sous quelque forme et de quelque manière que ce soit, est interdite sauf accord préalable et écrit de l'éditeur, en dehors des cas prévus par la législation en vigueur en France. Il est précisé que son stockage dans une base de données est également interdit. 


\title{
Orchestrating Platform Ecosystems: The Interplay of Innovation and Business Development Subsystems
}

\author{
Thierry ISCKIA \\ Institut Mines-Télécom Business School \\ Laboratoire en Innovation, Technologies, \\ Economie et Management (France) \\ thierry.isckia@imt-bs.eu \\ Mark DE REUVER \\ Delft University of Technology \\ Department Engineering Systems \\ and Services (The Netherlands) \\ G.A.deReuver@tudelft.nl \\ Denis LESCOP \\ Montpellier Business School (France) \\ d.lescop@montpellier-bs.com
}

\section{ABSTRACT}

In this paper, we analyze how to orchestrate platform ecosystems in order to ensure the commercialization of constant flows of innovations. We focus on platform-owners and how they orchestrate the coupling process between the innovation part of the ecosystem and the business development part of the ecosystem. We apply a life-cycle perspective, analyzing how these two subsystems are dynamically aligned through this coupling process. Three emblematic case studies illustrate platform-owners' choices regarding the management of this coupling process. Existing accounts of ecosystem orchestration are quite scarce in the academic literature and do not systematically acknowledge that innovation and business development are subsystems. By 
considering the two parts of ecosystems, our paper contributes to a more finegrained understanding of platform ecosystem orchestration.

KEYWORDS: Platform Ecosystems, Orchestration, Coupling Process, Sub-systems, Innovation

JEL Code: L190

In recent years, platform ecosystems have become a recurrent pattern of collective innovation (Ceccagnoli et al., 2012; Cennamo, Santaló, 2013; Tiwana, 2014, Parker et al., 2016; McIntyre, Srinivasan, 2017). Platform ecosystems create value by sequentially and/or simultaneously involving different players, communities, activities and resources. As such, ecosystems exhibit rules and governance mechanisms to involve independent players in pursuing distributed, collaborative, and cumulative innovation.

Platform ecosystems have flexible and scalable architectures of cooperation designed to leverage collective intelligence (Nambisan, Sawhney, 2007, 2011). Such a network-centric innovation approach focuses on cultivating innovation and creativity, on making, connecting and experimenting with the aim of turning shared knowledge into new products and/or services. Within platform ecosystems, digital technologies enable cooperation and effective innovation outcomes (Tan et al., 2015; Kazan et al., 2016; Nambisan et al., 2017). Resultant network effects drive a positive feedback loop - attracting the best and brightest partners to flock to the platform - thus nurturing the whole ecosystem dynamics.

The commercialization of the constant flow of innovations is a key prerequisite for platform ecosystems development. Several case studies investigated the role of platforms in the emergence and development of ecosystems (Attour, Peruta, 2013; Isckia, 2009; Isckia, 2011; Isckia, Lescop, 2009; Isckia, Lescop, 2013; Loilier, Malherbe, 2013; Isckia, Lescop, 2015) However, the academic literature on platforms lacks theories and empirical studies on platform orchestration; that is, the processes through which platform providers ensure a constant development and commercialization of innovations (Perks et al., 2017). Current research on orchestration with respect to platforms is highly conceptual and limited to the economic or technological rationale of platforms (Thomas et al., 2014). A systematic understanding of the platform orchestration process is missing.

Our central tenet in this paper is that platform orchestration involves a coupling between the two interrelated subsystems of a platform ecosystem. The function of the first subsystem is to produce new services, products and innovations based on the resource ensemble in the ecosystem. The second subsystem commercializes these innovations. These two subsystems imply 
that a platform owner should dynamically couple the production of new services and the needs of embarked communities. The orchestration of this coupling process calls for strategic and architectural choices at different stages of the ecosystem life cycle.

This paper aims to create an understanding of how platform owners orchestrate their ecosystems, through a process of coupling innovation and business development processes. We do so by developing a conceptual framework of coupling mechanisms, drawing upon separate sub-fields of ecosystem studies, i.e. platform design and governance, platform strategy and value creation (Jacobides et al., 2018; Järvi, Kortelainen, 2017; Teece, 2017). We then apply the framework to three emblematic case studies (Amazon, eBay and Apple), in order to explore the coupling mechanisms, providing a more fine-grained understanding of platform ecosystems' orchestration. We analyze these coupling mechanisms throughout the platform's lifecycle to better understand their implications on platform ecosystem evolution, focusing on the role of platform-owners and the choices they made to orchestrate this process. In the third part, we discuss our findings and contribution to the current body of knowledge in the field of platform ecosystem studies and orchestration.

\section{Conceptual Framework}

In our work we adopt an "ecosystem-as-affiliation" perspective (Adner, 2017), in between the engineering view which emphasizes that platforms are technological architectures that facilitate innovation (Iansiti, Levien, 2004; Gawer, 2014) and the economics view which considers them as an engine for market exchange and interactions (Van Alstyne et al., 2016; Parker et al., 2016). In this section, we first define platform ecosystems and the innovation dynamics that characterize them, and then we underline the relationships between the two parts of a platform ecosystem: innovation or innovation factory (IF) and business development (BD) (Maula et al., 2006).

\section{Core Concepts: Platform Ecosystems and Life Cycle}

Platform ecosystems are a particular kind of ecosystem that relies on digital platforms to facilitate innovation and creativity (Koenig, 2013; Choudary, 2015; Walton, 2017; Altman, Tushman, 2017). Platform owners generally design the whole architecture providing components, interfaces, data and services. As such, platform's architecture reflects platform-owner design choices. 
Following Evans and Schmalensee (2016), one-sided platforms enable interactions between homogeneous users that form a community, exhibiting direct externalities. Two-sided platforms mediate between two different communities with strong indirect externalities, whereas multi-sided platforms facilitate interactions between participants of more than two communities. In this perspective, the evolution from single-sided to two-sided and multisided platforms illustrates how platforms develop and grow over time by adding new sides and services to their initial value proposition.

Platform ecosystems stem from market failures, namely the need for coordination expressed by two or more communities (Roth, 2015; Fishman, Sullivan, 2016). Platform owners will assume this role designing an architecture of collaboration that solves this problem (Reillier, Reillier, 2017; Evans, Schmalensee, 2016; Evans et al., 2011; Evans, Schmalensee, 2010). As orchestrators, they must find the right balance between a shared vision and the interests of the different partners on board in order to facilitate their contributions and influence their behaviors.

In generic innovation management literature, orchestration has been defined as "the set of deliberate, purposeful actions undertaken by the hub firm as it seeks to create value (expand the pie) and extract value (gain a larger slice of the pie) from the network" (Dhanaraj, Parkhe, 2006, p. 659). In platform and ecosystems literature, orchestration is often applied without a strict definition. For instance, Tiwana (2014) uses orchestration as a metaphor to illustrate how directional control mechanisms do not work in platform ecosystems. Here, we follow the definition by Perks et al. (2017), who state that orchestration is a dynamic set of intentional activities to promote value creation in a platform ecosystem.

The sustainability of platform ecosystems relies on the platform owner's ability to design and orchestrate innovation processes (Iansiti, Levien, 2004; Nambisan et al., 2017). Indeed, platform ecosystems can hardly be managed in a goal-oriented fashion since the number of actors, communities, transactions, and interactions increases beyond the ability of what the platform owner can handle (Fjeldstad et al., 2012; Smedlun et al., 2018). This is what makes their management so challenging (Valkokari et al., 2016). Instead, platform ecosystems can be orchestrated by designing processes taking place among and between communities.

Platforms are complex systems that evolve gradually over time (Tiwana, 2014; Choudary, 2015; Parker et al., 2016). They generally expand either by building on new components and services or by connecting to other ecosystems. After reaching a critical mass in the number of participants and interactions, ecosystems develop in an evolutionary manner. 
Platform ecosystems promote experimentations that give rise to new ideas and concepts that may be embodied in new services or digital artifacts (Yoo et al., 2005). For digital platforms specifically, the intrinsic generativity of digital technologies is an essential feature that explains the proliferation of new products and services (Yoo et al., 2010; Boland et al., 2007).

Ecosystems are generally considered to pass through different phases in their life cycle. The most classical model comprises phases of birth, expansion, leadership, and self-renewal - or, if not self-renewal, death (Moore, 1993, 1996). Tiwana (2014) builds on ideas of technology dominance, and distinguishes phases leading towards an "ideal" technology solution and its progression towards a dominant design and proliferation. We build on both conceptualizations in this paper.

\section{From Innovation to Market: The Two Sides of Platform Ecosystems}

Innovation studies typically distinguish the development of innovations and technologies from the commercialization, dating back to first generation innovation models (Rothwell, 1992). Innovative new products/services will not yield value unless they are commercialized and this commercialization requires a close coupling of the developer of the new technology to the user (Teece, 1992). These coupling and feedback mechanisms must operate quickly and efficiently to ensure commercial success of innovation.

We argue that these two dimensions of innovation also hold for platform ecosystems. While platform ecosystems are highly diverse, they usually exhibit two interrelated dimensions: innovation or technology development and business development or technology commercialization. Figure 1 schematizes these two dimensions of platform ecosystems into two sides: the innovation factory (IF) and business development (BD) side. 
Figure 1 - The structure of platform ecosystems

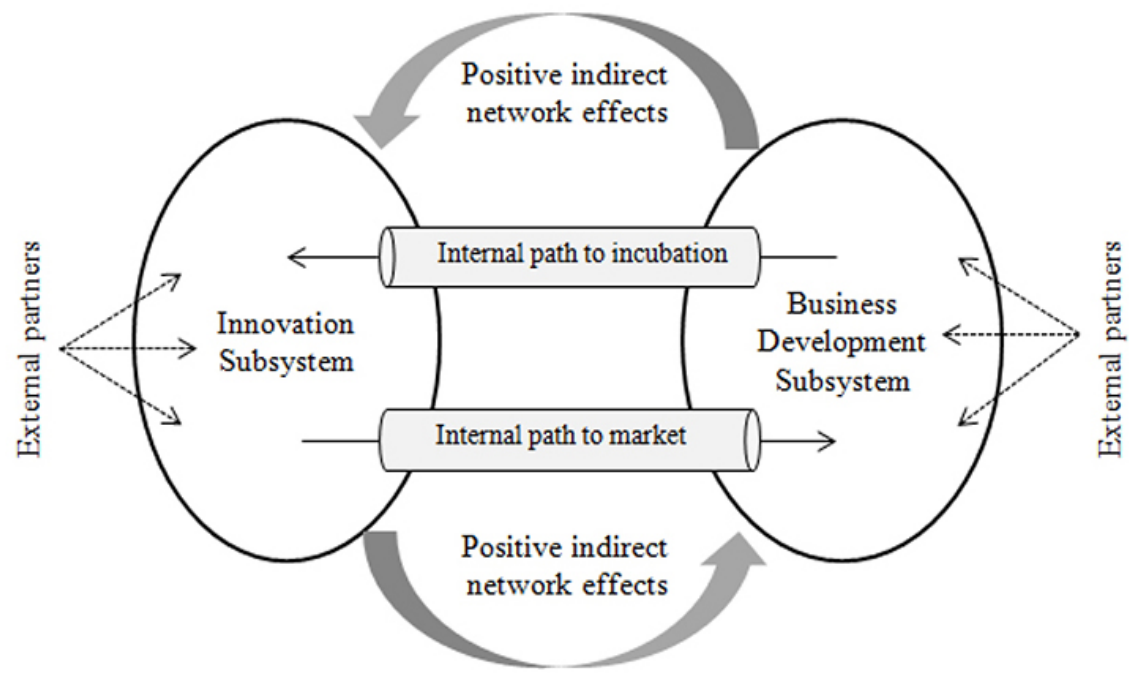

The right-hand side of the diagram represents the $\mathrm{BD}$ side of the ecosystem. The BD side gives access to consumers of products and services, and fulfils the function of commercialization and revenue generation. To interact with consumers, the BD side utilizes tools and services of the platform. Typical members of the BD side are complementors who utilize the platform to offer products and services. In this way, the BD side creates indirect externalities: the more complementors, the higher the value for consumers, and vice versa. $\mathrm{BD}$ members come mainly from outside the ecosystem but also from the IF side of the platform.

The left-hand side of Figure 1 represents the IF side. The IF side contains user groups and communities that actively change the functionalities of the platform, such as developers, startups and other freelancers. The IF is often developed via open innovation strategies (Chesbrough, 2003), through which platform owners open up (part of) the knowledge, resources, and skills. In our view, this side works like the ecosystem's incubator, improving customer experience and knowledge sharing while experimenting with new value propositions and offerings. We consider this side as the antechamber for the $\mathrm{BD}$ side. The path to the market for innovations, ideas or concepts developed within the IF is then tunneled through the platform.

The $\mathrm{BD}$ and IF side mutually reinforce each other, contributing to the growth of the platform ecosystem. As the BD side grows, a larger audience is reachable with new ideas, which in turn will attract more innovators on the IF side. Conversely, as the IF part grows and provides the platform with 
innovations and improvements, more consumers and complementors will be attracted on the BD side.

\section{Initial Research Framework}

We posit that the coupling between the BD and IF side requires orchestration from the platform owner. The nature of the relationships between platform owner and the communities, the intensity of interactions, the attractiveness of the platform, the design and architecture of the platform and even the strategy of the members depend on these orchestration efforts. When mapping the $\mathrm{BD}$ and IF conceptualization on the four stages of ecosystem life cycles, we develop a process model as displayed in Table 1. In this process model, we adapt the four phases from Moore (1996) while adding the ideas in Tiwana (2014). We posit that a platform ecosystem passes through stages in which first a solution to a systemic problem is found, identifying a suitable design and architecture, generally embodied in an original value proposition that makes it possible to on-board different actors on the platform (stage 1). As described in Roth (2015), platform strategies emerge in a context of market failures leading to loss of innovation opportunities. Next, after reaching an "ideal technology solution", the platform expands, either through the BD or IF side (stage 2). After that, the platform reaches the top of the technology maturity curve (stage 3) and eventual rejuvenation or decline (stage 4).

\section{Table 1 - Platform ecosystem life-cycle}

\begin{tabular}{l}
\hline In stage 1: Everything has to be in place. Platform owner searches for new \\
opportunities to reinvent value proposition for customers and have to design \\
a convenient and appealing platform. This stage is about identifying a suitable \\
architecture i.e. a design that eliminates pain points or frictions between \\
different groups or communities to attract a large enough audience to ignite \\
network effects. \\
\hline In stage 2: The platform expands either through its BD or IF side. Here, \\
it's about growing communities and reaching a critical mass in one side or \\
another. A failure to reach a critical mass (platform ignition) will make the \\
whole system collapse. The choice of the side to be developed first depends \\
on which is the main driver in the ecosystem: innovations or transactions? \\
At the end of stage 2, either the IF or BD is developed and the growth of \\
interactions becomes exponential (virtuous cycle). \\
\hline In stage 3: The platform is still growing and tries to reach maturity and full \\
leadership by eventually fully developing its second side. In the meanwhile \\
external ecosystem members are developing as well and may wish to increase \\
their opportunities embarking on other competing platforms (multi-homing). \\
\hline In stage 4: the platform ecosystem will start shrinking if nothing is done to \\
rejuvenate it. In this renewal stage, multi-homing may be a rule, creating huge \\
outflows of value, skills, competences and capabilities. But some multi-homers \\
may then quit the platform endangering it.
\end{tabular}




\section{Methodology}

We conduct case studies in order to understand the orchestration processes to couple the IF and BD sides of ecosystems throughout their life cycle. We follow an abductive reasoning approach based on contextualization (Yin, 2009) that uses inference to the best explanation (IBE) to develop potential explanations for observed phenomena (Ketokivi, Mantere, 2010). Through IBE, researchers compare potential theoretical explanations of a phenomenon (Lipton, 2009). Within this process, data and theoretical concepts are systematically combined (Strauss, Corbin, 1990; Dubois, Gadde, 2002) and have been examined simultaneously and discussed until a plausible explanation is found (Norton, 2003). This explanation must satisfy criteria for plausibility, simplicity, novelty and interestingness. Because IBE is a contextdependent reasoning process, we clearly acknowledge a certain level of subjectivity in our analysis.

We selected three emblematic cases, namely Amazon, eBay and Apple for their inherent interest and use in the literature, but also because their maturity allows assessing the four life cycle phases in our model. In terms of Yin (2009), we are in-between literal replication, since we chose cases which all passed the four stages of the life cycle, and theoretical replication, since the cases are different for anticipatable reasons. The cases have been purposively selected to replicate previous cases (the situation of each company regarding its original architecture of participation or design i.e. one-sided platforms versus two or multisided-platforms) and to fill theoretical categories illustrating different facets of platform orchestration.

We built a longitudinal study of each case focusing on the evolution of their respective ecosystems, ranging from 2007 to 2017. Our study is based both on secondary and primary data. We progressively updated the cases with numerous secondary data to better understand the context in which each case evolved. We mainly collected information from white papers, industry studies, books and academic articles, Factiva database, players' publications as well as from writings by experts in the relevant sectors. From this, we constructed a secondary database with a chronology of events in the evolution of each platform ecosystem. At the same time, the first author performed, between 2007 and 2017, a series of semi-structured interviews with eleven experts, four executives from Amazon, three from eBay and two from Apple. Semi-structured interviews were conducted either face-to-face during major international conferences or by email or video-conference. Interviews lasted between 60 and 90 minutes. When by e-mail, we sent a series of ten open questions for interviewees to answer. Questions were about how the platform 
ecosystem evolved through time while nurturing an ongoing innovation process and how platform owners orchestrate the dynamics.

Interviews were subjected to ex-ante thematic sorting, supplemented by ex-post sorting of emerging themes, in line with our abductive approach. Our chronological account of events served as the starting point for our analysis, enabling to identify how evolutionary paths resulted from platform owner choices. Regarding the validity of the research, we verified that our sorting method was sufficiently reliable and ensured construct validity by resorting to the three tactics prescribed by Miles and Huberman (2003): use of several heterogeneous data sources, establishment of a "chain of evidence" and validation of the case by key players.

\section{Orchestrating Innovation in Platform Ecosystem}

In this part, we analyze the orchestration of the coupling process between the BD and IF side of platform ecosystems within our case studies. We structure our analysis along the four stages of platform ecosystem life cycles, in order to better understand how the coupling process is carried out and affects innovation dynamics.

\section{The Birth Stage: Find Who Needs Whom and Why}

At this stage, the platform that will serve the potential business opportunity may not exist yet. The main objective of the platform owner is to identify such an opportunity designing a platform that will support the creation of a new value proposition for one community or another (IF or BD). Main strategic questions are how to design the value proposition of the platform, and which user group to onboard first. Our cases illustrate that the value proposition is not necessarily two-sided (see Table 2). In a two-sided context, the platform owner should identify the community that will bring the biggest flows of externalities and consequently which community of users to onboard first: consumers or complementors. This problem raises the so-called "chicken and egg" dilemma: participation of one user group depends upon the participation of the other. 
Table 2 - Platform strategy and platform design in the birth stage

\begin{tabular}{|l|l|l|l|}
\hline & Amazon & eBay & Apple iPhone \\
\hline $\begin{array}{l}\text { Platform } \\
\text { Strategy } \\
\text { (Business } \\
\text { opportuni- } \\
\text { ties) }\end{array}$ & $\begin{array}{l}\text { Brick \& mortar } \\
\text { bookshops do not } \\
\text { offer enough titles, } \\
\text { poor shopping } \\
\text { experience, } \\
\text { inconvenient... }\end{array}$ & $\begin{array}{l}\text { Second-hand } \\
\text { products are not } \\
\text { easy to sell since the } \\
\text { supply cannot reach } \\
\text { a sufficient demand }\end{array}$ & $\begin{array}{l}\text { The mobile Internet } \\
\text { is locked by mobile } \\
\text { network operators, } \\
\text { the walled garden } \\
\text { paradigm }\end{array}$ \\
\hline $\begin{array}{l}\text { Platform } \\
\text { design } \\
\text { (Value pro- } \\
\text { position) }\end{array}$ & $\begin{array}{l}\text { Offering a large } \\
\text { amount of titles } \\
\text { (long tail) and } \\
\text { helping consumers } \\
\text { in the discovery } \\
\text { procedure }\end{array}$ & $\begin{array}{l}\text { A marketplace } \\
\text { where people } \\
\text { can buy \& sell } \\
\text { (interactions) } \\
\text { various items with a } \\
\text { secured transactions } \\
\text { system, access to } \\
\text { member's profiles }\end{array}$ & $\begin{array}{l}\text { Creating a device } \\
\text { (smartphone) } \\
\text { able to provide } \\
\text { customers with } \\
\text { ubiquitous } \\
\text { Internet...and } \\
\text { content }\end{array}$ \\
\hline $\begin{array}{l}\text { Platform } \\
\text { type }\end{array}$ & Single-sided & Two-sided & Single-sided \\
\hline
\end{tabular}

Amazon's case is quite straightforward: Amazon started as an online bookstore i.e. a single-sided market selling only books to consumers, thanks to partnerships with big editors. Then the company progressively evolved into a network of merchant sites thanks to the Amazon Associates Program designed to increase book sales but also to improve the value proposition for consumers due to a larger selection of available books (Isckia, 2009; Isckia, Lescop, 2009; Isckia, Lescop, 2013). In Amazon's case, customers were already on board since they used Amazon web site for shopping purposes. Amazon progressively enrolled new partners (small and/or independent editors using a long tail strategy) who were interested in the visibility offered by Amazon's platform and the prospects for additional revenues and business opportunities. These opportunities were materialized later through the successive launch of Merchant@ program and Amazon Enterprise Solutions. In conceptual terms, Amazon clearly chose to develop first the BD part of its juvenile ecosystem. According to an interviewed expert: "After having industrialized affiliation programs such as Amazon Associates or Merchant@, Amazon's people realized that it was possible to move smoothly from a monolithic closed architecture to a network of services administered by several companies, but turned towards the same customers... This was the prelude to the development of Amazon web Services." (R.D.H, January 2014)

As illustrated with Amazon, platform owners should find a way to enroll potential partners or communities: "Bezos hoped to create a Windows for e-commerce" (R.D.H, January 2014). Amazon did have to figure out how to motivate participation i.e. resources to be shared or exposed: "With the launch of these new services (web services), Amazon enrolled a volunteer army 
of developers that costs Amazon almost nothing and morphed into a provider of technology" (P.B, July 2014). It can be any tangible assets such as user base, data, functionalities, computing capacities, tool kits or intangible assets such as patents, knowledge, reputation, trust, etc. The pricing structure is also important when it comes to easing access to the platform. Subsidizing the participation of community members or key-partners may help to ignite externalities.

According to Maula et al. (2006), two distinct processes make it possible to manage resource allocation in the context of systemic innovation: the foresight process and the shaping process. The first process describes how companies draw information about the evolution of technologies and markets but also about the resource allocation decisions of other firms by linking various actors in their environment. Following an expert we met: "Ebay, Amazon and Google were pioneers of APIs and they understood very quickly that APIs will improve the user experience by allowing developers to create new and more robust services for their platform." (K.L, March 2010)

The second process refers to the way companies influence the evolution of technologies and markets and the resource allocation decision of others in their ecosystem (Maula et al., 2006). According to a former Amazon executive: "Amazon has always been at the forefront of technology, and opening up this technology to its business partners is what has gotten the Street [independent developers] interested." (R.D, October 2013)

In eBay's case, the coupling process was more about igniting indirect externalities to boost revenues and ecosystem's development rather than nurturing innovation. For eBay, the orchestration process is slightly different since sellers and vendors were already on-board. As recalled by an expert we met: "From the beginning, eBay's goal has always been to facilitate transactions, attracting more and more people, expanding the goods traded on the platform, improving customer experience, making it safer and exciting, thus spreading the eBay's ecosystem." (K.L, March 2010)

In summary, in the birth stage, the platform ecosystem is structured as a private club with some partners selected by the platform owner. The system appears therefore intentionally closed: entry is discriminatory and under the sole discretion of the platform owner. Platform value proposition is the central here and a key feature of the orchestration process in the birth stage: it is implemented through a series of explorations and experimentations with early adopters. At this stage, architectural (design) and strategic choices (which community to embark first) are important and will guide the way the coupling process will be carried out in the next stages. While eBay started as two-sided platforms, Amazon and Apple on contrary started as single-sided 
platform. These two single-sided platforms focused first on the development of the $\mathrm{BE}$ sides of their ecosystem to boost transactions and increase reach. Hence, not all platforms start their lives the same way and history matters i.e. path dependencies play an important role in the first stage of the platform ecosystem life cycle.

\section{The Expansion Stage: In Search for the Right Design to Reach Critical Mass}

At the beginning of the expansion stage, the platform starts to be known by early adopters. The platform is in place and operates well, getting traction. The objective of the expansion stage is to reach and maintain a critical mass of participants in either the IF or BD side of the ecosystem. As we find in our case studies, which sub-system to develop depends on how the platform performed in the previous stage. For Amazon and eBay, increasing and developing exchanges and transactions in the BD part was a key success factor for their expansion strategy for at least two reasons.

First, it allows for economies of scale by increasing the number of interactions. To reinforce economies of scale, platform owners can increase platform's depth (Evans et al., 2008). Depth strategy attracts new members and at the same time saturates the current needs expressed on the platform by all participants. Hence, depth also entails higher switching costs for participants, which increases loyalty. Service innovations can increase these two effects, like customer recommendations, rating systems, centralized control of quality, search engines, and user friendly access to the platform.

Second, expanding the BD side creates economies of scope by bringing new partners (hence new products and services) on board. This is often referred as breadth strategy (Evans et al., 2008) i.e. attracting new communities on the platform. The overarching idea behind economies of scope and breadth is the idea of making the platform multi-sided or of improving its previous multi-sidedness. Hence, at the expansion stage, all platforms become two-sided. 
Table 3 - Platform strategy and platform design in the expansion stage

\begin{tabular}{|l|l|l|l|}
\hline & Amazon & eBay & Apple iPhone \\
\hline $\begin{array}{l}\text { Platform } \\
\text { (Bustragy } \\
\text { opportuni- } \\
\text { ties) }\end{array}$ & $\begin{array}{l}\text { Reinforcing } \\
\text { economies of scope } \\
\text { by finding new } \\
\text { business partners } \\
\text { (community), } \\
\text { relentlessly } \\
\text { improving customer } \\
\text { experience, } \\
\text { Get big fast }\end{array}$ & $\begin{array}{l}\text { Reinforcing } \\
\text { economies of scope } \\
\text { by finding new } \\
\text { business partners } \\
\text { (community) adding } \\
\text { new offerings and } \\
\text { items }\end{array}$ & $\begin{array}{l}\text { Some developers } \\
\text { create a system } \\
\text { (Cydia) to crack } \\
\text { install non-official } \\
\text { third-party Apps } \\
\text { which expresses } \\
\text { the need for } \\
\text { innovation and } \\
\text { customization }\end{array}$ \\
\hline $\begin{array}{l}\text { Platform } \\
\text { design } \\
\text { (Value pro- } \\
\text { position) }\end{array}$ & $\begin{array}{l}\text { Offering to partners } \\
\text { the access to } \\
\text { Amazon web site } \\
\text { and a channel to } \\
\text { easily liquidate their } \\
\text { inventories } \\
\text { Amazon affiliation } \\
\text { programs and } \\
\text { specialized services } \\
\text { Launch of 1st } \\
\text { generation Aws }\end{array}$ & $\begin{array}{l}\text { Upgrading brands } \\
\text { and products } \\
\text { visibility via new } \\
\text { services (Turbo } \\
\text { Lister, Seller's } \\
\text { Assistant, Selling } \\
\text { Manager) which } \\
\text { help automate the } \\
\text { selling process, } \\
\text { including the } \\
\text { Shipping Calculator, } \\
\text { Reporting tools, }\end{array}$ & $\begin{array}{l}\text { Creating a virtual } \\
\text { place (iTunes and } \\
\text { then App Store) } \\
\text { where developers } \\
\text { can offer their } \\
\text { Apps to iPhone } \\
\text { users } \\
\text { Service bundling }\end{array}$ \\
\hline $\begin{array}{l}\text { Platform } \\
\text { type }\end{array}$ & $\begin{array}{l}\text { Two-sided } \\
\text { Two-sided }\end{array}$ & Two-sided \\
\end{tabular}

Depth and breadth increase platform's thickness, and thus contribute to growth. Moreover, when carefully orchestrated, they can impede or discourage entries in the market by competing platforms. Depth coupled with breadth locks most of the market spaces that may be available to competitors. Following a former eBay top executive: "After spectacular organic growth, eBay has dried up the competition by tackling adjacent markets and gradually taking over almost all its competitors (Rent.com, Buzee.com, Shopping.com...)" (Y.R, April 2011). Depth and breadth raise barriers to entry and make the strategic spaces created on the platform nearly uncontestable. This pushes competitors to eventually go for head-to-head competition or to enter the system sideways (side competition or envelopment).

Platform expansion means managing a complex network of partners differing in their size, their business models, their commitment and loyalty to the platform. From this point of view, that kind of network cannot be centrally managed in the same way as in the first stage of the life cycle. Hence platform's expansion requires some kind of "laissez faire". Said differently, it raises the question of the degree of openness of the platform. The platform owner has to exercise less control on member profiles as to make entry more fluid and faster. 
In order to support the expansion of the BD side, the design or the architecture of the platform has to evolve. According to an expert: "It was Cydia's development that made Apple's people realize that they had gold in their hands, and that they needed to open the AppStore and offer many more Apps to customize your iPhone" (B.S, February 2009). Entry on the platform should be made easier and knowledge encapsulated within the platform must be turned fully explicit as to ensure its sharing within the BD side. In this context, boundary objects such as SDKs or APIs (Star, 2010; Carlile, 2002, 2004) play an important role. However, improving platform's thickness may trigger congestion, which can be avoided by maintaining quality of interactions. Platform designs must be highly scalable and flexible to adapt quickly and efficiently to this growing number of interactions (Choudary, 2015).

To facilitate platform entry and to ensure enough depth, the platform owner must enrich the platform design with new services or functionalities. This can be done via two different approaches: either the platform owner creates these functions in the IF side (Amazon One-click Shopping) or acquires them through the BD side (Paypal or Skype for eBay, Alexia for Amazon, Shazam or Lala for Apple). According to another former eBay top executive: "The acquisition of other marketplaces, coupled with the development of payment solutions (PayPal) and communication services (Skype), was intended to facilitate interactions within eBay community, and to nurture growth beyond our original platform." (F.C, June 2014)

During the expansion stage, the platform thus becomes open, encouraging new communities to enter the $\mathrm{BD}$ side of the ecosystem. Their ability to explore new business models nurtures the expansion of the ecosystem (Chesbrough, 2011; Doz, Kosonen, 2010; Lu, Ramamurthy, 2011). These communities encompass start-ups, developers and established firms in adjacent markets (side-player). While some of them join the platform to explore new business opportunities, others join the platform to gain knowledge.

In summary, at the expansion stage, the platform ecosystem is structured as an open club with non-discriminatory membership. The ecosystem therefore appears intentionally open. This opening increases the number of participants and deepens the complexity of interactions. BD-focused platforms may more easily start as multi-sided businesses than IF-focused platforms. Apple iPhone started out as a single-sided platform, and the other side of the ecosystem (developers) came on board only once there is a critical mass of end-users. Clearly, eBay started as two-sided platforms in the birth stage. In this case, the platform was designed as an engine for growth to fuel the $\mathrm{BD}$ side, since the two groups were already on board. On the contrary, during the expansion stage both Amazon and Apple upgraded their platforms 
design in order to support collective innovation at the IF side, starting with the developers' side for Apple and with affiliates and later third-party players for Amazon. From this point of view, they first had to attain a critical mass of users on one side to attract other groups of players on the other side thus igniting network externalities. These elements characterize the orchestration process during the expansion stage: openness and sharing of resources to stimulate innovation once the critical mass has been reached and value creation/capture to support ecosystem development.

\section{The Leadership Stage: Clustering and Multi-Homing}

At this stage, the platform has reached its critical mass at the $\mathrm{BD}$ and/or IF side, and is supporting a wide and complex network of interactions. The growth eventually starts to decelerate. Moreover, as the size and number of communities increase, the influence of the platform owner on the BD side withers. Hence, the main strategic goal for of the platform owner is to maintain leadership and to sustain growth. The implementation of these objectives may take different path as shown in our cases.

Table 4 - Platform strategy and platform design in the leadership stage

\begin{tabular}{|c|c|c|c|}
\hline & Amazon & eBay & Apple iPhone \\
\hline $\begin{array}{l}\text { Platform } \\
\text { Strategy } \\
\text { (Business } \\
\text { opportuni- } \\
\text { ties) }\end{array}$ & $\begin{array}{l}\text { Sustaining growth } \\
\text { and leadership } \\
\text { through the } \\
\text { creation of a IF and } \\
\text { new services }\end{array}$ & $\begin{array}{l}\text { Sustaining growth } \\
\text { and leadership } \\
\text { through the } \\
\text { creation of a IF and } \\
\text { new services }\end{array}$ & $\begin{array}{l}\text { Sustaining growth } \\
\text { with technological } \\
\text { and functional } \\
\text { evolution of the } \\
\text { platform }\end{array}$ \\
\hline $\begin{array}{l}\text { Platform } \\
\text { design } \\
\text { (Value propo- } \\
\text { sition) }\end{array}$ & $\begin{array}{l}\text { Developing IF by } \\
\text { introducing new } \\
\text { services (next-gen } \\
\text { AWS), } \\
\text { Developing } \\
\text { ubiquity } \\
\text { (M-commerce), } \\
\text { Upgrading and } \\
\text { developing new } \\
\text { services to other } \\
\text { firms and partners, }\end{array}$ & $\begin{array}{l}\text { Developing IF by } \\
\text { introducing APIs } \\
\text { and SDK } \\
\text { Developing } \\
\text { ubiquity } \\
\text { (M-Commerce) } \\
\text { Developing } \\
\text { new services to } \\
\text { other firms and } \\
\text { business partners } \\
\text { (e-Commerce } \\
\text { solutions, CRM, ...) }\end{array}$ & $\begin{array}{l}\text { Upgrading iOS } \\
\text { to spur new } \\
\text { developments, } \\
\text { Implementing new } \\
\text { features on the } \\
\text { devices, } \\
\text { Transforming App } \\
\text { Store (IF) into a } \\
\text { IF-BD }\end{array}$ \\
\hline Platform type & Multi-sided & Multi-sided & Two-sided \\
\hline
\end{tabular}

Amazon and eBay have followed the same strategy, improving their ecosystem by creating and nurturing the IF side. In these cases, the IF side provides developers and partners with access to APIs and SDKs to build on solutions for e-commerce that will improve transactions on their platforms. For a former Amazon executive we met: "With AWS our goal was to encourage the 
use of Amazon content in ways we would never have been able to develop on our own. We worked on different business models for AWS from the very begining, but the real goal was innovation" (C.B, January 2013). eBay more particularly focused on development for the mobile App market. As of 2013, eBay counts 1.8 million active users of its API and SDK in its IF.

As shown in Figure 1, there is a positive ripple effect between the IF and $\mathrm{BD}$ sides. To benefit from this effect, the platform owner has to create bridges between the IF and $\mathrm{BD}$ in order to ensure a path to market for innovators in the IF and a path to incubation for participants in the $\mathrm{BD}$ side. This is an important characteristic of the orchestration process at this stage.

In the Apple case, the IF evolved progressively in its functions towards operating as BD. The IF and the BD sides overlap: the App Store is a place for innovators but also a place for merchants who can work and exchange with developers (Hyrynsalmi, 2015). By coupling BD and IF sides through strategic tunneling, platform owners reinforce their control of the ecosystem and the main outputs: innovations and revenues. Following a former Apple top executive: "Apple has progressively opened up its native iOS so that thirdparty developers who build apps can offer more $i$ S services for their own products... but at the very beginning God Father (i.e. Steve Jobs) was very concerned that they might compromise the integrity of the platform... He was obsessed with controlling their Apps and very soon a quality control process was put in place". "In addition, the AppStore has proven to be a great way to increase sales of their devices" (B.G, September 2010).

Participants in the BD side evolve too. They thrive for their survival and success. Some of them are able to attract other participants and to create subsystems of innovation or platforms around their own products or services (piggybacking or forking). Then, the BD side starts to form clusters of interdependent innovations, developments, interactions, services and products grow here and there in the BD landscape. The ecosystem does not appear anymore as a network centered on the platform of the founding company. Clustering is not a problem per se. In any growing complex system of interactions, clusters occur. Clustering implies that a part of the survival of the ecosystem does not rely anymore on the founder's platform but also on other relatively important members and their respective platforms. In other words, the $\mathrm{BD}$ side of the focal ecosystem forms clusters of innovation, which in turn become the IF side for novel platform ecosystems. A former Amazon manager reported: "It was clear that with the development of Amazon, many vendors were going to need help to integrate their offer on Amazon platform...At this time integrating with Amazon was an arduous task... that's what gave birth to MindCorps - bought out by Amazon in 2000 - ... Later, when it became evident 
that Amazon was the place to be, I founded Morse Best Innovation which spun off Mercent to help vendors to integrate their systems with Amazon's through Mercent Commerce System... These three companies would never have come into being without Amazon." (E.B, July 2015)

Cluster players share the fate of the whole ecosystem, which implies most of them will not try to act negatively on it. Like the platform-owner, they fight for the development and survival of the whole ecosystem: they act cooperatively by supporting a part of the system on their own. The platform-owner cannot act against clusters without jeopardizing the survival of the ecosystem. Instead, the platform owner should use them and integrate them in the ecosystem governance. These institutional mechanisms should be fine-tuned taking into account the clusters as units of control while upgrading platform design purposively. From this point of view, clusters impose decentralization and delegation of power in the BD side.

Some players may wish to go further than clustering and multi-home. If multi-homing is a prerequisite for their development, it has a deleterious effect on the original platform ecosystem. If players multi-home, the complementary offerings are no longer exclusive for a platform but commodities. A commodity is not distinctive but rather a must-have to remain competitive: no one can imagine an App store without social games like Clash of Clan or Candy Crush nor a marketplace without an online payment system. When possible, the platform owner can envelop it (Eisenmann et al., 2011) and standardize it through design (Amazon One-click shopping). Whatever the strategy of the platform owner, multi-homing means outflows or destruction of value and innovation in its platform ecosystem.

In summary, during the leadership stage, the platform ecosystem is still structured as an open club with non-discriminatory membership. However, especially in the $\mathrm{BD}$ side, clusters appear and may transform part of platform value proposition. With clusters, multi-homing strategies and competitive pressure also emerge. Multi-homing implies frictions in the ecosystem as multi-homers do not act cooperatively anymore: the platform is becoming just one of their delivery channels and their fate does not rely anymore on the original platform. At this stage, the orchestration process is about managing or anticipating clustering, attracting and retaining communities in the $\mathrm{BD}$ side in order to maintain platform's competitiveness. Here, part of the orchestration process plays out in the ability of platform owners to fully embrace their role of leader providing communities in the BD side with vision, caring and guidance for future developments. This often implies upgrading platform design through service innovations, which requires actions in the IF side of the ecosystem. 


\section{The Renewal Stage: Exploring New Horizons}

At this stage, if nothing is done, the ecosystem will slowly decay. Some players (among which those who build clusters) will stop investing in the BD side, will leave it or will launch their own platform. The platform owner may be tempted to use a dominator strategy (Iansiti, Levien, 2004) draining the whole remaining value from the ecosystem, hence accelerating the attrition process. To avoid this, the platform has to enter a new cycle of development. The renewal stage is the premises of this cycle and looks like a rebirth stage. However, the platform owner can now rely on its fully functional and mature ecosystem. Table 5 illustrates some renewal strategies found in our cases.

Table 5 - Platform strategy and platform design in renewal stage

\begin{tabular}{|c|c|c|c|}
\hline & Amazon & eBay & Apple iPhone \\
\hline $\begin{array}{l}\text { Platform } \\
\text { Strategy } \\
\text { (Business } \\
\text { opportuni- } \\
\text { ties) }\end{array}$ & $\begin{array}{l}\text { Finding new way to } \\
\text { deliver products } \\
\text { (Drones, brick- } \\
\text { and-mortar stores, } \\
\text { Amazon Go...) } \\
\text { Creating new } \\
\text { devices } \\
\text { (Kindle, FireTV, } \\
\text { Dash Buttons...) } \\
\text { and A.I-based } \\
\text { services, loT } \\
\text { Cross platform } \\
\text { strategy }\end{array}$ & $\begin{array}{l}\text { Becoming a } \\
\text { ubiquitous digital } \\
\text { wallet for consumers } \\
\text { and merchants } \\
\text { around the world, } \\
\text { Develop Ayden } \\
\text { payment system }\end{array}$ & $\begin{array}{l}\text { Working on } \\
\text { new devices, } \\
\text { new features } \\
\text { and design, new } \\
\text { services (iCloud } \\
\text { platform, Apple' } \\
\text { A.I) } \\
\text { Cross platform } \\
\text { strategy as a post } \\
\text { iPhone strategy } \\
\text { loT }\end{array}$ \\
\hline $\begin{array}{l}\text { Platform } \\
\text { design } \\
\text { (Value propo- } \\
\text { sition) }\end{array}$ & $\begin{array}{l}\text { Building new } \\
\text { features with and } \\
\text { for key partners, } \\
\text { Upgrading } \\
\text { platform design } \\
\text { (platform as a } \\
\text { service) } \\
\text { Designing for } \\
\text { more flexibility, } \\
\text { scalability and } \\
\text { community } \\
\text { engagement }\end{array}$ & $\begin{array}{l}\text { Building new } \\
\text { services } \\
\text { Taking } \\
\text { personalization to } \\
\text { the next level using } \\
\text { A.I } \\
\text { Chatbot shopping } \\
\text { assistance Fully } \\
\text { integrate Ayden } \\
\text { streamlined payment } \\
\text { methods }\end{array}$ & $\begin{array}{l}\text { Crafting new } \\
\text { products and } \\
\text { services (Apple } \\
\text { Watch, TV, iCloud } \\
\text { platform, Apple' } \\
\text { A.I) for existing } \\
\text { and new partners } \\
\text { Designing new } \\
\text { Apple Stores }\end{array}$ \\
\hline Platform type & Multi-sided & Multi-sided & Multi-sided \\
\hline
\end{tabular}

The main challenge at this stage is to avoid the disintegration of the interactions forged during the previous stages: renewal is essential to ensure survival of the ecosystem. In the renewal stage, the ecosystem becomes mature. Large parts of it are now stabilized (for instance, Amazon as an online store, as an ASP, Apple as a device maker and a content provider) delivering comfortable flows of revenue and profits. Renewal stage relies on 
the leader's capabilities to leverage its own platform to find new paths of development and to project its platform into new market spaces (A.I, media, M-business, IoT...). For instance, Amazon chooses to enter the entertainment markets by creating a new line of products and services, among which Fire TV, Amazon Game Studios and more recently Amazon Video and Amazon Music Unlimited. Fire TV and Amazon Game Studios were clearly two strategic moves to prepare the release of a 3D smartphone launched in summer 2014 and Amazon's entry in the mobile device business. eBay follows a more classical renewal strategy by focusing its effort on one part of its platform ecosystem: payment services. eBay works in the development of Paypal as an ubiquitous digital portfolio for any consumers and merchants in partnership with financial institutions around the world. Paypal expands way beyond eBay ecosystem boundaries. By abandoning Paypal and partnering with Ayden, eBay now intends to further improve its customer experience. Apple follows its usual strategy of embarking its whole ecosystem in the renewal of the hardware (iPhone X-gen and 11-gen): new screen, new technologies, new design and functionalities. In the renewal stage, platform owner's dynamic capabilities are essential to identify and create new opportunities of development for the ecosystem. The renewal stage also depends on the vision provided by the leader during the leadership stage. The renewal stage is in essence a phase of ideation, exploration and experimentations. Here, the main challenge in terms of orchestration is to maintain communities in the ecosystem by motivating them with new ideas and challenges. It means being able to capitalize on existing knowledge and relationships to foster the emergence of new ideas around its vision.

As in the birth stage, the platform owners need to identify and gather the key partners who will support new projects. This relational strategy can be used to maintain important clusters in the ecosystem: the cluster holders then become a key partner in the ecosystem. Exclusivity contracts can help sealing the relationships, preventing multi-homing threats. Then, the leader can implement a new structure in the ecosystem: platform of platform (PoP). The original platform can run as a host for other platforms supporting a constellation of clusters or smallest platforms (Tan et al., 2015): clusters will then be able to develop on their own. Being independent entities, these clusters can be used to explore new business opportunities without jeopardizing the whole ecosystem.

In summary, in this critical phase of renewal, clusters may reinforce the resilience of the system. In such a context, orchestrating means rethinking the role of the original platform design and strategy. All ideas and projects may not lead to major developments. As the leader, the platform owner has 
to choose the best options for the ecosystem to be developed (BD), dynamically reallocating bundles of resources via wise design choices (IF). At this stage, the orchestration process relies on platform owners' capability to leverage its platform to enter new paths of developments, stimulating innovation while exploring new market spaces. The ecosystem changes its structure and becomes mainly an open club with non-discriminatory access, but containing private clubs (clusters in development) managed by the platform leader. Future developments of the platform are nested or embedded in these innovative clusters and will bring the orchestration process to a next stage.

\section{Conclusion and Discussion}

In all three cases studied, some communities contribute directly to the collective innovation effort while others participate more in exploring new horizons and their commercialization opportunities. Our framework and our case studies allow us to better understand the mechanisms that allow these two dimensions to be coupled over time through the orchestration process. These case studies illustrate how the coupling process is performed and achieved through a series of choices that focus on the architecture and design of the platform and the strategic objectives associated with each stage of its life cycle.

In the birth stage, the orchestration process is straightforward; the platform owner must design a value proposition for a community (single-side market) and/or choose which one it will focus on if it is a two-side market. As a corollary, it will be necessary to define accordingly which architecture to set up and the associated governance structure.

The orchestration process in the expansion stage is about reaching a critical mass in one community or another by playing on platform's breadth or depth. At this stage the platform becomes more inclusive and open. Knowledge sharing in the IF will help to maintain a steady flow of innovations while giving $\mathrm{BD}$ members opportunities to develop and spread new services. The coupling process must allow both to ensure openness and sharing of resources to stimulate innovation and value creation/capture to support ecosystem development.

In the leadership stage, the platform owner must strive to maintain and nurture platform's growth. Here, the coupling process aims at supporting the IF by creating exchange zones that provide $\mathrm{BD}$ communities opportunities to cross-fertilize knowledge and ideas in search for growth levers. This process must also support the development of clusters and control multi-homing and 
commoditization risks by integrating new services into platform core architecture.

In the maturity stage, the platform owner must integrate existing clusters by becoming a platform of platforms (PoP) i.e. by hosting other platforms to explore new market spaces without endangering its platform. In this case, the coupling process requires to go a step further in the integration of new services and market exploration while maintaining community engagement and keeping a critical mass of users.

Our case studies show that orchestration is done at two main levels. The first one focuses on managing the mobility of resources, the stability of the ecosystem and the appropriation of innovation (IF). The second focuses on ensuring the platform ecosystem's development and sustainability (BD). These two dimensions refer the two sides of platform ecosystems described in our conceptual framework. From this point of view, orchestrating platform ecosystems rely on platform-owner capabilities to accommodate both innovation and business development over time. Our results also highlight the different facets of orchestration, which occur at different stages of the ecosystem' life cycle:

- Ensuring the relevance of innovation and the attractiveness of the of the value proposition over time.

- Sharing resources to nurture on-going collective innovation.

- Managing membership over time so as not to undermine the ecosystem's development.

- Ensuring the ecosystem stability, maintaining a critical mass of users so as not to break network externalities that have governed its development in previous stages.

- Sharing the value co-created by members at the different stages of the life cycle.

While our results confirm some previous work (Nambisan, Sawhney, 2007, 2011), they also allow us to go a step further. Indeed, while Nambisan and Sawhney (2007) distinguish two distinct orchestration models (the "innovation-integrator" and the "platform leader" models), our results show that these two models complement each other and are closely intertwined. Thus, if the orchestrator implements the collaborative architecture (Nambisan, Sawhney, 2011) it simultaneously shares resources to encourage ecosystem members to innovate (IF) and integrates their contributions, it also guides the dynamics of innovation and development of the ecosystem (BD).

Given that empirical studies on platform ecosystem orchestration are scarce, we can only compare our findings to limited related work. Comparing 
our findings to Perks et al. (2017), we broadly find similar orchestration mechanisms: envisioning network value for the platform, inducing innovativeness of network members towards the platform, legitimizing the platform through the ecosystem and involving the ecosystem in organizational adjustments towards the platform. However, our findings show that these mechanisms are not sequential but rather simultaneous at each stage of platform ecosystem development. Finally, and contrary to Perks et al. (2017) position, we find that the orchestration process is everything but a routine, as the coupling process between IF and $\mathrm{BD}$ sides of ecosystems must be fine-tuned over time and can hardly being encapsulated within a routine. As illustrated in our case studies, the orchestration process is a dynamic process that partly relies on experimentation.

A limitation of our paper is that we draw upon three success cases of platform development. As platform development fails more often than it succeeds (Cusumano et al., 2019), it might be worthwhile to apply our model to failure cases too. Further, our analysis focuses on large firms being platform providers, which arguably have more resources to actively orchestrate their ecosystems. On the other hand, Amazon and eBay did both start as small start-ups, so, arguably, our choice to study cases that passed through all stages of platform life-cycles inherently favors selecting large players. A final limitation is that our framing of the cases assumes that platform orchestration is a directive and conscious activity, which, as previous studies show (Saarikko, 2016), is not always the case in platform evolution.

Our framework combines the engineering and economics view of platform ecosystems and emphasizes the role of the ecosystem orchestrator both as a market designer and a market explorer. It thus sheds light on the coupling process between the two sides of platform ecosystems. Managing such a process is tricky. Platform owners have to shape their platform architectures, design control mechanisms, value creation mechanisms and manage associated knowledge in a coherent and dynamic way over time to nurture collective innovation. Strategizing in platform ecosystems means that the coupling process is designed so that he can dialogically handle the tensions between the various ago-antagonistic dimensions associated with orchestration: control/generativity, open/closed, individual/collective. Ago-antagonist systems rely both on antagonism, that is the opposition of two forces acting on a common receptor - the platform -, and agonism, that is their cooperation (Bernard-Weil, 1999). Orchestrators have to manage the balance of these forces.

Everything starts with a wannabe leader that will have to design a flexible architecture of collaboration in order to achieve a specific goal (innovation) 
while managing interdependencies (Altman, Tushman, 2017) and ago-antagonist tensions. Addressing such interactions requires a set of capabilities that are yet uncommon for traditional companies (Teece, 2017). Throughout the ecosystem's life cycle, the platform-owner has to think strategically considering the effect of its decision on the ecosystem and the feedbacks or countereffects created by the strategic moves of other players. The platform-owner should thus be both an orchestrator driving the development of its ecosystem and a chess-master that integrate the reactions of others players in its own decision process. As the platform ecosystem develops, its complexity increases which pushes the system to evolve from a centered network to a decentralized structure of platform of platforms (PoP). This will make the orchestration even more complex and challenging.

\section{REFERENCES}

ADNER, R. (2017), Ecosystem as Structure: An Actionable Construct for Strategy, Journal of Management, 43(1), 39-58.

ALTMAN, E. J., TUSHMAN, M. L. (2017), Platforms, Open/User Innovation, and Ecosystems: A Strategic Leadership Perspective, in Entrepreneurship, Innovation, and Platforms, Emerald Publishing Limited, 177-207.

ATTOUR, A., PERUTA, M. D. (2016), Architectural Knowledge: Key Flows and Processes in Designing an Inter-Organisational Technological Platform, Knowledge Management Research E Practice, 14(1), 27-34.

BERNARD-WEIL, É. (1999), La théorie des systèmes ago-antagonistes, Debat Paris, 106120.

BOLAND, JR. R. J., LYYTINEN, K., YOO, Y. (2007), Wakes of Innovation in Project Networks: The Case of Digital 3-D Representations in Architecture, Engineering, and Construction, Organization Science, 18(4), 631-647.

CARLILE, P. R. (2002), A Pragmatic View of Knowledge and Boundaries: Boundary Objects in New Product Development, Organization Science, 13(4), 442-455.

CARLILE, P. R. (2004), Transferring, Translating, and Transforming: An Integrative Framework for Managing Knowledge across Boundaries, Organization Science, 15(5), 555-568.

CECCAGNOLI, M., FORMAN, C., HUANG, P., WU, D. J. (2012), Co-Creation of Value in a Platform Ecosystem: The Case of Enterprise Software, MIS Quarterly, 263-290.

CENNAMO, C., SANTAlO, J. (2013), Platform Competition: Strategic Trade-Offs in Platform Markets, Strategic Management Journal, 34(11), 1331-1350.

CHESBROUGH, H. (2003), Open Innovation: The New Imperative for Creating and Profiting from Technology, Boston, Harvard Business School Press.

CHESBROUGH, H. (2011), Open Services Innovation: Rethinking Your Business to Grow and Compete in a New Era, John Wiley and Sons. 
CHOUDARY, S.-P. (2015), Platform Scale: How an Emerging Business Model Helps Startups Build Large Empires with Minimum Investment, Platform Thinking Labs Pte. Ltd.

PARKER, G. G, VAN ALSTYNE, M. W., CHOUDARY, S.-P. (2016), Platform Revolution: How Networked Markets are Transforming the Economy and How to Make Them Work for You, WW Norton \& Company.

CUSUMANO, M. A., GAWER, A., YOFFIE, D. B. (2019), The Business of Platforms: Strategy in the Age of Digital Competition, Innovation, and Power, New York, HarperCollins Publishers.

DHANARAJ, C., PARKHE, A. (2006), Orchestrating Innovation Networks, Academy of Management Review, 31(3), 659-669.

DUBOIS, A., GADDE, L.-E. (2002), Systematic Combining: An Abductive Approach to Case Research, Journal of Business Research, 55(7), 553-560.

DOZ, Y. L., KOSONEN, M. (2010), Embedding Strategic Agility: A Leadership Agenda for Accelerating Business Model Renewal, Long Range Planning, 43(2), 370-382.

EISENMANN, T., PARKER, G., VAN ALSTYNE, M. (2011), Platform Envelopment, Strategic Management Journal, 32(12), 1270-1285.

EVANS, D. S., SCHMALENSEE, R. (2010), Failure to Launch: Critical Mass in Platform Businesses, Review of Network Economics, 9(4).

EVANS, D. S., HAGIU, A., SCHMALENSEE, R. (2008), Invisible Engines: How Software Platforms Drive Innovation and Transform Industries, MIT Press.

EVANS, D. S., SCHMALENSEE, R., NOEL, M. D., CHANG, H. H., GARCIA-SWARTZ, D. D. (2011), Platform Economics: Essays on Multi-Sided Businesses, Ed Competition Policy International.

EVANS, D. S., SCHMALENSEE, R. (2016), Matchmakers: The New Economics of Multisided Platforms, Harvard Business Review Press.

FJELDSTAD, Ø. D., SNOW, C. C., MILES, R. E., LETTL, C. (2012), The Architecture of Collaboration, Strategic Management Journal, 33(6), 734-750.

FISMAN, R., SULLIVAN, T. (2016), The Inner Lives of Markets: How People Shape Them and They Shape Us, PublicAffairs.

GAWER, A. (2014), Bridging Differing Perspectives on Technological Platforms: Toward an Integrative Framework, Research Policy, 43(7), 1239-1249.

HYRYNSALMI, S. (2015), Letters from the War of Ecosystems, Doctoral dissertation, University of Turku, Finland.

IANSITI M., LEVIEN R. (2004), The Keystone Advantage: What the New Dynamics of Business Ecosystems Mean for Strategy, Innovation, and Sustainability, Harvard Business School Press.

ISCKIA, T. (2009), Amazon's Evolving Ecosystem: A Cyber-bookstore and Application Service Provider, Canadian Journal of Administrative Sciences, 26(4), 332-343.

ISCKIA, T. (2011), Ecosystèmes d'affaires, stratégies de plateforme et innovation ouverte: vers une approche intégrée de la dynamique d'innovation, Management Avenir, 6, 157176.

ISCKIA, T., LESCOP, D. (2009), Open Innovation within Business Ecosystems: A Tale from Amazon.com, Communications ES Stratégies, 74, 37-67. 
ISCKIA, T., LESCOP, D. (2013), Platform-Based Ecosystems: Leveraging Network Centric Innovation, in Ben Letaïfa, S., Gratacap, A., Isckia, T. (eds), Understanding Business Ecosystems: How Firms Succeed in the New World of Convergence, Brussels, De Boeck.

ISCKIA, T., LESCOP, D. (2015), Strategizing in Platform-Based Ecosystems: Leveraging Core Processes for Continuous Innovation, Communications $\mathcal{E}$ Stratégies, 99, 91-111.

JACOBIDES, M. G., CENNAMO, C., GAWER, A. (2018), Towards a Theory of Ecosystems, Strategic Management Journal, 39(1), 2255-2276.

JÄRVI, K., KORTELAINEN, S. (2017), Taking Stock of Empirical Research on Business Ecosystems: A Literature Review, International Journal of Business and Systems Research, 11(3), 215-228.

KAZAN, E., WEE TAN, C., LIM, E. T. (2016), Towards a Framework of Digital Platform Competition: A Comparative Study of Monopolistic \& Federated Mobile Payment Platforms, Journal of Theoretical and Applied Electronic Commerce Research, 11(3), 50-64.

KETOKIVI, M., MANTERE, S. (2010), Two Strategies for Inductive Reasoning in Organizational Research, Academy of Management Review, 35(2), 315-333.

KOENIG, G. (2013), Business Ecosystems Revisited, in Ben Letaifa, L., Gratacap, A., Isckia, T. (eds)., Understanding Business Ecosystems: How firm Succeed in the New World of Convergence, Brussels, De Boeck, 69-83.

LIPTON, P. (2009), Understanding without Explanation, Scientific Understanding: Philosophical Perspectives, 43-63.

LOILIER, T., MALHERBE, M., (2013), Experimentation and the Development of EcoSystemic Competencies in the Field of Contactless Mobile Services, in Ben Letaïfa, S., Gratacap, A., Isckia, T. (eds). Understanding Business Ecosystems: How Firms Succeed in the New World of Convergence, Brussels, De Boeck.

LU, Y., RAMAMURTHY, K. R. (2011), Understanding the Link between Information Technology Capability and Organizational Agility: An Empirical Examination, MIS Quarterly, 35(4), 931-954.

MCINTYRE, D. P., SRINIVASAN, A. (2017), Networks, Platforms, and Strategy: Emerging Views and Next Steps, Strategic Management Journal, 38(1), 141-160.

MAULA, M. V., KEIL, T., SALMENKAITA, J. P. (2006), Open Innovation in Systemic Innovation Contexts, in Chesbrough, H., Vanhaverbeke, W., West, J. (eds.), Open Innovation: Researching a New Paradigm, Oxford University Press, 241-257.

MILES, M. B., HUBERMAN, A. M. (2003). Analyse des données qualitatives, Brussels, De Boeck Supérieur.

MOORE, J. F. (1993), Predators and Prey: A New Ecology of Competition, Harvard Business Review, 71(3), 75-86.

MOORE, J. F. (1996), The Death of Competition: Leadership and Strategy in the Age of Business Ecosystems, Harper Business.

SAWHNEY, M., NAMBISAN, S., (2007), The Global Brain: Your Roadmap for Innovating Faster and Smarter in a Networked World, Pearson Education India.

NAMBISAN, S., SAWHNEY, M. (2011), Orchestration Processes in Network-Centric Innovation: Evidence from the Field, Academy of Management Perspectives, 25(3), 40-57. 
NAMBISAN, S., LYYTINEN, K., MAJCHRZAK, A., SONG, M. (2017), Digital Innovation Management: Reinventing Innovation Management Research in a Digital World, MIS Quarterly, 41(1).

NORTON, J. D. (2003), A Material Theory of Induction, Philosophy of Science, 70(4), 647670.

PARKER, G. G., VAN ALSTYNE, M. W., CHOUDARY, S. P. (2016), Platform Revolution: How Networked Markets Are Transforming the Economy-And How to Make Them Work for You, New York, WW Norton \& Company.

PERKS, H., KOWALKOWSKI, C., WITELL, L., GUSTAFSSON, A. (2017), Network Orchestration for Value Platform Development, Industrial Marketing Management, 67, 106-121.

REILliER, L. C., REILliER, B. (2017), Platform Strategy: How to Unlock the Power of Communities and Networks to Grow Your Business, London, Taylor \& Francis.

ROTH, A. E. (2015), Who Gets What - and Why: The New Economics of Matchmaking and Market Design, Houghton Mifflin Harcourt.

ROTHWELL, R. (1992), Developments Towards the Fifth Generation Model of Innovation, Technology Analysis E3 Strategic Management, 4(1), 73-75.

SAARIKKO, T. (2016), Platform Provider by Accident, Business $\mathcal{E}$ Information Systems Engineering, 58(3), 177-191.

SMEDLUND, A., FAGHANKHANI, H., IKÄVALKO, H., TURKAMA, P. (2018), Platform Ecosystem Orchestration for Efficiency, Development, in Collaborative Value Co-creation in the Platform Economy, Springer, Singapore, 29-40.

STAR, S. L. (2010), This is not a Boundary Object: Reflections on the Origin of a Concept, Science, Technology \&ु Human Values, 35(5), 601-617.

STRAUSS, A., CORBIN, J. (1990), Basics of Qualitative Research. Grounded Theory Procedures and Techniques, Newbury Park, Sage Publications.

TAN, B., PAN, S. L., LU, X., HUANG, L. (2015), The Role of IS Capabilities in the Development of Multi-Sided Platforms: The Digital Ecosystem Strategy of Alibaba. com, Journal of the Association for Information Systems, 16(4), 248-280.

TEECE, D. J. (1992), Competition, Cooperation, and Innovation: Organizational Arrangements for Regimes of Rapid Technological Progress, Journal of Economic Behavior E⿱乛龰 Organization, 18(1), 1-25.

TEECE, D. J. (2017), Dynamic Capabilities and (Digital) Platform Lifecycles, in Entrepreneurship, Innovation, and Platforms, Emerald Publishing Limited, 211-225.

TIWANA, A. (2014), Platform Ecosystems: Aligning Architecture, Governance, and Strategy, Morgan Kaufmann.

THOMAS, L. D., AUTIO, E., GANN, D. M. (2014), Architectural Leverage: Putting Platforms in Context, Academy of Management Perspectives, 28(2), 198-219.

VALKOKARI, K., AMITRANO, C., C., BIFUlCO, F., VAlJAKKA, T. (2016), Managing Actors, Resources, and Activities in Innovation Ecosystems - A Design Science Approach, in H. Afsarmanesh, L. Camarinha-Matos, A. Lucas Soares (eds), Collaboration in a Hyperconnected World, IFIP Advances in Information and Communication Technology. 
VAN ALSTYNE, M. W., PARKER, G. G., CHOUDARY, S. P. (2016), Pipelines, Platforms, and the New Rules of Strategy, Harvard Business Review, 94(4), 54-62.

WALTON, N. (2017), Ecosystems Thinking and Modern Platform-Based Ecosystem Theory, in The Internet as a Technology-Based Ecosystem, London, Palgrave Macmillan, 85-117.

YIN, R. (2009), Case Study Research: Design and Methods, Fourth Edition, Applied Social Methods Series, Vol 5, Sage.

YOO, Y., LYYTINEN, K., YANG, H. (2005), The Role of Standards in Innovation and Diffusion of Broadband Mobile Services: The Case of South Korea, The Journal of Strategic Information Systems, 14(3), 323-353.

YOO, Y., LYYTINEN, K., THUMMADI, V., WEISS, A. (2010), Unbounded Innovation with Digitalization: A Case of Digital Camera, in Annual Meeting of the Academy of Management. 